\title{
Pectolytic Activity of Phytopathogenic Xanthomonads
}

\author{
By M. P. STARR AND S. NASUNO \\ Department of Bacteriology, University of California, \\ Davis, California, 95616, U.S.A.
}

(Accepted for publication 19 October 1966)

\begin{abstract}
S UMMARY
Cultures of 10 of 19 nomenspecies of the genus Xanthomonas liquefied a nutrient pectate gel. None of the 19 nomenspecies produced either hydrolytic polygalacturonase or pectin trans-eliminase. Seventeen of the nomenspecies showed a detectable, at times weak, pectinesterase activity. Seven of the 10 pectate-liquefying nomenspecies excreted polygalacturonic acid transeliminase in culture fluids containing pectin as growth substrate. The enzymological basis, if any, is not at present known for the liquefaction of the nutrient pectate gel in the remaining three xanthomonads, which all lacked both the hydrolytic and the eliminative enzymes. Pectinesterase and polygalacturonic acid trans-eliminase were produced inducibly on pectin by most $X$. campestris cultures which were examined; some strains of this phytopathogen formed polygalacturonic acid trans-eliminase constitutively on glucose, but pectinesterase was never constitutive. The polygalacturonic acid trans-eliminase excreted by the tested xanthomonads degraded polygalacturonic acid in a random manner. The major end-products were unsaturated di- and trigalacturonic acids, accompanied by lesser amounts of saturated mono-, di-, and tri-galacturonic acids.
\end{abstract}

\section{INTRODUCTION}

The symptoms caused in plants by phytopathogenic bacteria of the genus Xanthomonas are sufficiently unlike those induced by the pectolytic soft-rot Erwinia, Bacillus and Pseudomonas species to foster the impression that xanthomonads lack ability to degrade pectic substances. Nevertheless, several reports attest to the pectolytic activity of xanthomonads. For example, one of the present writers had observed two decades ago (Burkholder \& Starr, 1948) that 38 of 77 xanthomonad cultures (14 of 25 Xanthomonas spp.) could liquefy a pectate gel, although more slowly and less vigorously than did soft-rot erwinias. Similar observations and crude enzymological surveys were subsequently presented by other workers (Sabet \& Dowson, 1951; Smith, 1958a, $b$; Dye, 1960). By present standards, a certain confusion about the nomenclature of pectic substances and enzymes is evident in some of these writings. An assortment of methodological and interpretative procedures, ingenious or naive, were used; these make almost impossible any intelligent comparisons among the results obtained by individual workers. Moreover, following the discovery by Albersheim, Neukom \& Deuel (1960) of fungal pectin trans-eliminase (PTE), there have been elucidated eliminative splits of pectic substances in soft-rot phytopathogenic bacteria such as Erwinia carotovora (Starr \& Moran, 1962) and Bacillus polymyxa (Nagel \& Vaughn, $1961 b$ ), in addition to the classical hydrolytic action (Kraght \& Starr, 1953) which has recently been re-examined with purified enzyme in Erwinia carotovora (Nasuno \& 
Starr, 1966a). Except for our preliminary abstract (Starr \& Nasuno, 1963), there has been no published work on the eliminative split of pectic substances by xanthomonads; indeed, not much is known about the enzymology of pectic substances by Xanthomonas, by comparison with the knowledge now available for other groups of microbes. A comprehensive study was undertaken with the hope of unravelling the kinds of pectolytic activity in various xanthomonads, and their distribution among the various so-called species (actually, nomenspecies; see Stolp, Starr \& Baigent, 1965). The present report surveys the pectolytic capacities of a representative assortment of xanthomonads; the enzymological details with respect to a typical strain will be published separately (Nasuno \& Starr, 1967).

\section{METHODS}

Chemicals. Pectin N.F. (68\% esterified) and polygalacturonic acid (no. 491) were obtained from Sunkist Growers, Inc. (Corona, California); they were used without additional treatment. 0 -(4-Deoxy- $\beta$-L-threo-hexopyranos-4-enyluronic acid)-( $1 \rightarrow 4)$ D-galacturonic acid (unsaturated digalacturonic acid) was kindly supplied by Dr C. W. Nagel (Department of Horticulture, Washington State University, Pullman, Washington). Di-, tri-, and tetra-galacturonic acids were the generous gifts of Dr H. J. Phaff (Department of Food Science and Technology, University of California, Davis, California). Pure D-galacturonic acid was prepared from the commercial product by recrystallization from acetone.

Cultural methods. Stock cultures of 27 species or strains of the genus Xanthomonas were obtained from the International Collection of Phytopathogenic Bacteria (ICPB), maintained in this Department; they were grown on slopes of yeast extract, glucose and $\mathrm{CaCO}_{3}$ (YDC) agar during the course of this programme.

A nutrient sodium pectate gel (Starr, 1947) was used for liquefaction tests. This medium consisted of Exchange Brand sodium ammonium pectate (Sunkist Growers, Inc., Corona, California), $3 \mathrm{~g}$.; $10 \%$ (w/v) $\mathrm{CaCl}_{2} .2 \mathrm{H}_{2} \mathrm{O}, 0.6 \mathrm{ml}$., N-NaOH, $0.9 \mathrm{ml}$; yeast extract (Difco), $1 \mathrm{~g}$; distilled water, $100 \mathrm{ml}$; $\mathrm{pH} 6.4$ after autoclaving.

The basal medium consisted of two parts: (i) pectin N.F., 5 g. $200 \mathrm{ml}$.; (ii) $\mathrm{KH}_{2} \mathrm{PO}_{4}$, 1.6 g.; $\mathrm{Na}_{2} \mathrm{HPO}_{4}, 1.6$ g. $; \mathrm{MgSO}_{4} .7 \mathrm{H}_{2} \mathrm{O}, 0.2 \mathrm{~g}$; $\mathrm{CaCl}_{2} .2 \mathrm{H}_{2} \mathrm{O}, 0.1 \mathrm{~g}$; ; yeast extract (Difco Laboratories, Inc., Detroit, Michigan), $5 \mathrm{~g}$.; total volume, $800 \mathrm{ml}$. Both solutions were adjusted to $\mathrm{pH} 6.8$ autoclaved separately, and mixed before use. For the calcium-deficient medium, the $\mathrm{CaCl}_{2}$ was omitted.

Bacterial growth in liquid culture was determined as the dry weight of bacteria/ml. culture.

Enzyme preparations. The bacteria were grown at $28^{\circ}$ in a basal medium, or in a calcium-deficient medium, containing pectin, on a rotary shaker $(3 \mathrm{~cm}$. amplitude and 100 rotations/min.) for $48 \mathrm{hr}$. When pectin was replaced with glucose, the bacteria were grown for $24 \mathrm{hr}$, at which time maximum growth had been attained. The culture fluid was centrifuged at $6000 \mathrm{~g}$ for $10 \mathrm{~min}$., filtered through a $0.45 \mu$ Millipore filter (Millipore Filter Corp., Bedford, Massachusetts), dialysed against distilled water for $24 \mathrm{hr}$ at $4^{\circ}$, and tested for the presence of pectic enzymes.

Assays of pectic enzymes. Heated enzyme was used as a control in all enzyme assays. Pectinesterase (PE) activity was determined by a titration method. The reaction mixture contained $1 \%(\mathrm{w} / \mathrm{v})$ pectin N.F., $0 \cdot 1 \mathrm{M}-\mathrm{NaCl}$, and $10 \%(\mathrm{v} / \mathrm{v})$ enzyme solution in a total volume of $10 \mathrm{ml}$. The reaction mixtures were adjusted to $\mathrm{pH} 7.0$ after 
addition of enzyme, incubated at $30^{\circ}$ for $1 \mathrm{hr}$, and titrated to $\mathrm{pH} 7.0$ with 0.01 $\mathrm{N}-\mathrm{NaOH}$ at the end of the incubation period. PE activity was expressed in terms of $\mu$ moles ester hydrolysed $/ \mathrm{hr} / \mathrm{ml}$. reaction mixture, under the above conditions.

Polygalacturonic acid trans-eliminase (PATE) activity was determined, by spectrophotometry. Reaction mixtures contained $10 \%(\mathrm{v} / \mathrm{v})$ enzyme solution, in 0.05 M-glycine- $\mathrm{NaOH}$ buffer (pH 9.5), in a total volume of $6 \mathrm{ml}$. Samples $(0.5 \mathrm{ml}$.) were removed immediately after enzyme was added and again after $1 \mathrm{hr}$ incubation at $30^{\circ}$, placed in $4.5 \mathrm{ml}$. or $9.5 \mathrm{ml}$. of $0.01 \mathrm{~N}-\mathrm{HCl}$ to stop enzyme action, and the extinction measured in the Beckman model DU spectrophotometer. The relative activity of PATE is expressed as the increase in extinction at $235 \mathrm{~m} \mu / \mathrm{hr}$, under the above conditions.

The same principle used in the PATE assay was used for the attempted detection of pectin trans-eliminase (PTE) activity. Reaction mixtures containing $10 \%(\mathrm{v} / \mathrm{v})$ enzyme solution, $0.5 \%(\mathrm{w} / \mathrm{v})$ pectin N.F., and $0.4 \mathrm{M}-\mathrm{NaCl}$ in $0.05 \mathrm{M}$-sodium acetate buffer (pH 5.2) were incubated at $30^{\circ}$ for 1-24 hr, and the extinction measured at $235 \mathrm{~m} \mu$ (Edstrom \& Phaff, $1964 a$ ).

The iodometric method of Yemm (1935) was used to detect polygalacturonase (PG) activity by following the release of reducing groups during hydrolysis of the substrate. Replicate flasks were set up containing $10 \%$ (v/v) enzyme solution, $0.5 \%$ $(\mathrm{w} / \mathrm{v})$ polygalacturonic acid, and $0.1 \mathrm{M}-\mathrm{NaCl}$ in $0.05 \mathrm{M}$-sodium acetate buffer $(\mathrm{pH} 5 \cdot 2)$ in a total volume of $5 \mathrm{ml}$. After suitable periods of reaction $(1 \mathrm{hr}$ and $24 \mathrm{hr}$ ), the reaction was stopped by adding $0.35 \mathrm{ml}$. of $\mathrm{M}-\mathrm{Na}_{2} \mathrm{CO}_{3}$ and then $2 \mathrm{ml}$. of the iodine solution were added; the initial values were obtained by adding the $\mathrm{Na}_{2} \mathrm{CO}_{3}$ before the enzyme. After 20 min., the reaction mixture was acidified with $0.8 \mathrm{ml}$. of $2 \mathrm{~N}^{-\mathrm{H}_{2}} \mathrm{SO}_{4}$ and the liberated iodine was titrated with $0 \cdot 01 \mathrm{~N}-\mathrm{Na}_{2} \mathrm{~S}_{2} \mathrm{O}_{3}$ with starch as indicator.

Paper chromatography. After $24 \mathrm{hr}$ of incubation, samples $(1 \mathrm{ml}$.) were taken from each reaction mixture for paper chromatography. The tubes containing these samples were immersed in boiling water for 5 min., and the samples dried at $70^{\circ}$ over $\mathrm{CaCl}_{2}$ under vacuum after removing cations with Dowex 50 cation exchange resin in the hydrogen form. The residues were dissolved in $0.1 \mathrm{ml}$. distilled water, and $10 \mu \mathrm{l}$. of each sample was chromatographed on Whatman no. 4 paper. The solvent was a mixture of pyridine + ethyl acetate + acetic acid + water $(5+5+1+3$ by vol.) applied for $18 \mathrm{hr}$ at room temperature. The marker spots were mono-, di-, tri-, and tetragalacturonic acids, and unsaturated di-galacturonic acid. The silver nitrate reagent (Block, Durrum \& Zweig, 1955) was used to detect saturated and unsaturated oligogalacturonides and galacturonic acid. Under these conditions, $0.02 \mu$ mole galacturonic acid gives a definite black spot at room temperature. Unsaturated compounds were also located by spraying with a solution containing $0.01 \%(\mathrm{w} / \mathrm{v})$ quinine sulphate and $0.04 \mathrm{~N}$-sulphuric acid in $95 \%(\mathrm{v} / \mathrm{v})$ ethanol in water (Edstrom \& Phaff, $1964 \mathrm{~b}$ ). After drying at room temperature, the presence of the unsaturated compounds was detected under ultraviolet radiation as a dark spot on a light violet to white fluorescent field. Amounts of less than $0 \cdot 2 \mu$ mole of unsaturated digalacturonic acid were readily located by this method. 


\section{RESULTS AND DISCUSSION}

\section{Pectic enzymes produced by Xanthomonas species}

Tables 1 and 2 summarize the results of the pectate gel liquefaction tests and the assays for the various pectic enzymes in xanthomonad culture supernatant fluids. Even though every culture examined showed a good growth on the pectate gel medium (probably at the expense of the yeast extract in the medium), cultures of only 10 of 19 species were able to bring about prompt liquefaction of the gel; viz. Xanthomonas badrii, $X$. campestris, $X$. carotae, $X$. geranii, X. lespedezae, $X$. manihotis, $X$. nakataeolitorii, $X$. papavericola, $X$. pelargonii, $X$. ricinicola. These results are generally in accord with those presented earlier by Burkholder \& Starr (1948) and Dye (1960).

\section{Table 1. Distribution of pectolytic enzymes in Xanthomonas species}

The strains are designated by their accession numbers in the International Collection of Phytopathogenic Bacteria (ICPB); many of the cultures are deposited also in the National Collection of Plant Pathogenic Bacteria, Harpenden. Liquefaction $(a)$ of nutrient pectate gel (Starr, 1947) was scored after $24 \mathrm{hr}$ at $28^{\circ}$. Growth (b) is expressed as mg. dried cells per $\mathrm{ml}$. culture fluid. Pectinesterase (PE) activity $(c)$ is reported in terms of the increase in $\mu$ moles of carboxyl groups per $\mathrm{ml}$. reaction mixture per hour. Polygalacturonic acid transeliminase (PATE) activity $(d)$ is recorded as change per hour in absorbancy at $235 \mathrm{~m} \mu$; reaction mixtures were diluted 20 -fold with $0.01 \mathrm{~N}-\mathrm{HCl}$ before measuring absorbancy.

Enzymic activity*

\begin{tabular}{|c|c|c|c|c|c|}
\hline Species & $\begin{array}{l}\text { Strain } \\
\text { ICPB }\end{array}$ & $\begin{array}{l}\text { Liquefaction } \\
\qquad(a)\end{array}$ & $\begin{array}{l}\text { Growth } \\
\text { (b) }\end{array}$ & $\begin{array}{l}\mathrm{PE} \\
(c)\end{array}$ & $\begin{array}{l}\text { PATE } \\
\qquad(d)\end{array}$ \\
\hline$X$. badrii & Хв 103 & + & 0.76 & $1 \cdot 10$ & 1.63 \\
\hline$X$. beticola & Хв 109 & - & 0.39 & 0.05 & 0 \\
\hline$X$. campestris & XC 135 & + & 0.98 & 0.09 & 0.69 \\
\hline$X$. carotae & xC 139 & + & $1 \cdot 17$ & 0.57 & $0 \cdot 14$ \\
\hline$X$. corylina & $\mathrm{xC} 12$ & - & 0.46 & 0.05 & 0 \\
\hline$X$. desmodii-gangetici & XD 106 & - & 0.63 & 0 & 0 \\
\hline$X$. geranii & XG 10 & + & $1 \cdot 05$ & 0.02 & 0.06 \\
\hline$X$. holcicola & XH 3 & - & $0 \cdot 83$ & 0.06 & 0 \\
\hline$X$. hyacinthi & XH 110 & - & 0.83 & 0 & 0 \\
\hline$X$. juglandis & XJ 103 & - & 0.51 & $0 \cdot 10$ & 0 \\
\hline$X$. lespedezae & XL 2 & + & $0 \cdot 48$ & $0 \cdot 10$ & 0 \\
\hline$X$. manihotis & XM 12 & + & $1 \cdot 06$ & 0.02 & 0.55 \\
\hline$X$. nakatae-olitorii & XN 101 & + & 0.95 & 0.01 & 0 \\
\hline X. papavericola & XP 5 & + & $1 \cdot 24$ & $0 \cdot 61$ & $0 \cdot 02$ \\
\hline$X$. pelargonii & $\mathrm{XP} 8$ & + & 0.84 & 0.04 & 0 \\
\hline$X$. phaseoli & XP 104 & - & 0.83 & 0.01 & 0 \\
\hline$X$. ricinicola & XR 4 & + & 0.33 & 0.67 & $0 \cdot 83$ \\
\hline$X$. taraxaci & XT 11 & - & $0 \cdot 48$ & 0.04 & $0 \cdot 12$ \\
\hline X. vesicatoria & xV 3 & - & $0 \cdot 10$ & 0.09 & 0 \\
\hline
\end{tabular}

* Not even a trace of hydrolytic polygalacturonase or pectin trans-eliminase activity was detectable in any of the culture filtrates.

Some pectinesterase (PE) activity was found in all pectate-liquefying species and even in some cultures which did not liquefy the gel. The level of PE activity in Xanthomonas badrii, $X$. campestris (strains ICPB-XC 147 and ICPB-XC 149), $X$. carotae, $X$. papavericola and $X$. ricinicola is comparable to that reported for Pseudomonas solanacearum (Winstead \& Walker, 1954), Erwinia carotovora (Goto \& Okabe, 1962a) and $X$. malvacearum (Abo-El-Dahab, 1964), based on the same enzyme concentration and 
the same reaction time. The lesser amounts of PE produced by other species or strains also are comparable on the same bases to that excreted by Pseudomonas marginalis (Ceponis \& Friedman, 1959; Nasuno \& Starr, 1966b).

Table 2. Production of pectolytic enzymes by various strains of Xanthomonas campestris grown in the medium containing glucose or pectin as substrate*

\begin{tabular}{|c|c|c|c|c|c|c|c|c|}
\hline \multirow[b]{3}{*}{$\begin{array}{l}\text { Strain } \\
\text { ICPB }\end{array}$} & \multirow[b]{3}{*}{$\begin{array}{l}\text { Plant } \\
\text { sources }\end{array}$} & \multirow[b]{3}{*}{$\begin{array}{l}\text { Lique- } \\
\text { faction } \\
(a)\end{array}$} & \multicolumn{3}{|c|}{ Glucose-grown organisms } & \multicolumn{3}{|c|}{ Pectin-grown organisms } \\
\hline & & & \multirow[b]{2}{*}{$\begin{array}{l}\text { Growth } \\
(b)\end{array}$} & \multicolumn{2}{|c|}{ Enzymic activity } & \multirow[b]{2}{*}{$\begin{array}{l}\text { Growth } \\
\text { (b) }\end{array}$} & \multicolumn{2}{|c|}{ Enzymic activity } \\
\hline & & & & $\begin{array}{l}\text { PE } \\
\text { (c) }\end{array}$ & $\begin{array}{l}\text { PATE } \\
(d)\end{array}$ & & $\begin{array}{r}\mathrm{PE} \\
(c)\end{array}$ & $\begin{array}{l}\text { PATE } \\
(d)\end{array}$ \\
\hline xc 4 & Horseradish & - & $1 \cdot 24$ & 0 & 0 & $0 \cdot 47$ & $0 \cdot 04$ & 0 \\
\hline XC 7 & Cabbage & + & 0. & 0 & 0. & & $0 \cdot 12$ & $0 \cdot 12$ \\
\hline xc 10 & Turnip & + & $1 \cdot 42$ & 0 & $0 \cdot 1$ & 0.42 & 0.06 & 0.95 \\
\hline XC 15 & Cabbage & + & $1 \cdot 10$ & 0 & 0.0 & 0.44 & 0.02 & $0 \cdot 30$ \\
\hline XC 117 & Cauliflower & + & $1 \cdot 12$ & 0 & 0.0 & 0.41 & 0.02 & 0.04 \\
\hline xc 132 & Candytuft & + & $1 \cdot 26$ & 0 & $0 \cdot 10$ & 0.71 & 0.02 & 0.45 \\
\hline Xc 147 & Cabbage & + & 1.00 & 0 & 0.43 & 0.37 & 0.78 & 0.36 \\
\hline XC 149 & Brussels sprout & - & $1 \cdot 62$ & 0 & 0.04 & 0.51 & 0.47 & 0.07 \\
\hline
\end{tabular}

* See the sublegend of Table 1 for notes; the only exception in the present instance is that the samples for determination of PATE activity $(d)$ were diluted ten-fold with $0.01 \mathrm{~N}-\mathrm{HCl}$ before measuring absorbancy.

The excretion of polygalacturonic acid trans-eliminase (PATE) was observed in all pectate-liquefying species except Xanthomonas lespedezae, X. nakatae-olitorii and X. pelargonii. Since these three cultures do not produce any polygalacturonase (PG), although they do form pectinesterase, the basis for liquefaction of the pectate gel deserves further study. Dye (1960), who observed a similar pattern, suggested that weak liquefaction of a pectate gel might well have been caused by other than enzymic factors. To further complicate the picture, it must be noted that PATE is shown in the present study to be produced by $X$. taraxaci which does not, however, detectably liquefy the pectate gel.

Under the assay-conditions used in the present study, neither polygalacturonase nor pectin trans-eliminase activity could be detected, even after $24 \mathrm{hr}$ of reaction, in the culture supernatant fluids of any tested xanthomonads. According to Goto \& Okabe (1962b), Erwinia carotovora can produce a pectic glycosidase active at $\mathrm{pH} 4 \cdot 0$ only when grown in a medium at very low calcium ion levels. However, polygalacturonase was not excreted by any xanthomonad cultures, even in a calcium-deficient medium. It might be noted that polygalacturonic acid trans-eliminase production in this calcium-deficient medium was either remarkably reduced (Xanthomonas badrii, $X$. campestris, $X$. carotae, $X$. ricinicola) or completely halted $(X$. geranii, $X$. manihotis, $X$. papavericola, $X$. taraxaci) in the case of xanthomonads which normally form PATE in the presence of calcium. Static culture conditions were ineffective in stimulating polygalacturonase excretion by xanthomonads, although this enzyme is produced by yeasts in static culture (Luh \& Phaff, $1954 a, b$ ).

The production of a 'pectin polygalacturonase' was reported by Dye (1960) to occur in many xanthomonads. It is more likely that the enzyme so designated by Dye is actually a combination of polygalacturonic acid trans-eliminase (PATE) and pectinesterase rather than the hydrolytic enzyme. He determined this enzyme activity 
in growing cultures on a pectic agar media adjusted to $\mathrm{pH} 6 \cdot 2-7 \cdot 0$ at which $\mathrm{pH}$ value the PATE of xanthomonads is still somewhat active (Nasuno \& Starr, 1967). Moreover, a shift in $\mathrm{pH}$ value of the growth medium to the alkaline range favourable for PATE normally occurs when xanthomonads are grown on the medium used by Dye. The distribution of PATE + pectinesterase among the various xanthomonad species coincides well with Dye's (1960) report of what he terms 'protopectinase' ('PP') activity in xanthomonads (actually measured by Dye as maceration of potato tuber tissue). The good agreement between distribution of 'PP' and PATE + pectinesterase suggests that the so-called ' $\mathrm{PP}$ ' of xanthomonads in most cases is probably a combination of polygalacturonic acid trans-eliminase (PATE) and pectinesterase.

\section{Effects of substrate on pectic enzyme production}

Various studies have shown that some pectic enzymes are inducible, whereas others seem to be constitutive; most pectic enzymes produced by phytopathogenic bacteria are inducible. Kraght \& Starr (1953), Ozawa \& Okamoto (1956) and Goto \& Okabe $(1962 b)$ reported that pectin was superior to glucose as the carbon source for production of pectic glycosidase by Erwinia species. Similar results were found for Bacillus polymyxa by Nagel \& Vaughn (1961 a), and for Xanthomonas malvacearum by Abo-ElDahab (1964). When eight strains of $X$. campestris were grown in a medium containing glucose but no pectic substances, there was no pectinesterase activity in the culture fluids of any strain; however, polygalacturonic acid trans-eliminase (PATE) was produced to some extent under these conditions by some strains (Table 2). On the other hand, in all these strains, pectinesterase was induced by the presence in the growth medium of pectin, which remarkably stimulated PATE production by some strains. Constitutive production of PATE is, thus, clear in several $X$. campestris strains. Somewhat similar results were recently found in Pseudomonas marginalis (Nasuno \& Starr, 1966 b), in which one of two strains excreted PATE regardless of the presence of a pectic substrate in the culture medium.

\section{End-products from pectic substances formed by Xanthomonas species}

Table 3 shows the results of paper chromatographic analysis of the breakdown products from polygalacturonic acid by polygalacturonic acid trans-eliminase (PATE) excreted by various Xanthomonas species or strains. The experimental conditions were $10 \%(\mathrm{v} / \mathrm{v})$ enzyme solution, $0.5 \%(\mathrm{w} / \mathrm{v})$ substrate, and $0.001 \mathrm{M}-\mathrm{CaCl}_{2}$ in $0.05 \mathrm{M}-$ glycine- $\mathrm{NaOH}$ buffer ( $\mathrm{pH} 9.5)$, and a reaction time of $24 \mathrm{hr}$ at $30^{\circ}$. With enzyme preparations showing high activity, the reaction products were unsaturated di- and trigalacturonic acids accompanied by saturated mono-, di-, tri- and tetra-galacturonic acids. With weakly active enzyme preparations, the mono- and di-galacturonic acid and sometimes even the unsaturated di-galacturonic acid were not detectable in the case of some xanthomonads

In earlier work it was believed that some 'polygalacturonase' preparations degrade the substrate completely to galacturonic acid, whereas others seemed to produce only oligalacturonides but not galacturonic acid. For example, in the reaction mixture with the pectic glycosidase from Pseudomonas marginalis and a pectic substrate, Ceponis \& Friedman (1959) could not detect galacturonic acid which recently was found to be formed with concentrated enzyme under similar conditions (Nasuno \& 
Starr, 1966b). With tomato polygalacturonase, the reaction product was first thought to be pentagalacturonic acid (McColloch \& Kertesz, 1949), then tri-, di-, and galacturonic acids (Roelofsen, 1953); eventually, mono- and di-galacturonic acids were confirmed as the real end-products (Luh, Leonard \& Phaff, 1956).

Table 3. Paper chromatographic analysis of the reaction products from polygalacturonic acid by polygalacturonic acid trans-eliminase produced by various Xanthomonas species

\begin{tabular}{|c|c|c|c|c|c|c|c|c|}
\hline \multirow[b]{3}{*}{ Species } & \multirow{3}{*}{$\begin{array}{l}\text { Strain } \\
\text { ICPB }\end{array}$} & \multicolumn{6}{|c|}{ Galacturonides formed* } & \multirow[b]{3}{*}{$\Delta E_{253} \ddagger$} \\
\hline & & \multicolumn{4}{|c|}{ Saturated } & \multicolumn{2}{|c|}{ Unsaturated } & \\
\hline & & Mono- & Di- & Tri- & Tetra- & Di- & Tri- $\dagger$ & \\
\hline$X$. badrii & Хв 103 & $(+)$ & ++ & + & $(+)$ & +++ & ++ & 0.500 \\
\hline$X$. campestris & $\mathrm{xC} 7$ & & + & + & + & ++ & ++ & 0.305 \\
\hline$X$. campestris & xc 10 & $(t)$ & + & + & + & ++ & ++ & 0.480 \\
\hline$X$. campestris & xc 15 & . & . & . & + & $(+)$ & . & $0 \cdot 046$ \\
\hline$X$. campestris & XC 117 & & & . & + & $(+)$ & & 0.035 \\
\hline$X$. campestris & XC 132 & $(+)$ & + & + & + & ++ & ++ & 0.320 \\
\hline$X$. campestris & Xc 135 & $(+)$ & + & + & $(+)$ & ++ & ++ & 0.470 \\
\hline$X$. campestris & XC 147 & $(+)$ & + & + & + & ++ & ++ & $0 \cdot 445$ \\
\hline$X$. campestris & xc 149 & . & + & + & + & + & + & $0 \cdot 110$ \\
\hline$X$ carotae & XC 139 & . & + & + & ++ & ++ & ++ & 0.300 \\
\hline$X$. geranii & XG 10 & . & & + & + & + & . & $0 \cdot 135$ \\
\hline$X$. lespedezae & $\mathrm{xL} 2$ & . & $(+)$ & + & ++ & $(+)$ & ++ & $0 \cdot 085$ \\
\hline$X$. manihotis & XM 12 & + & $+t$ & + & $(+)$ & +++ & ++ & 0.545 \\
\hline$X$. papavericola & XP 5 & . & & . & + & $(+)$ & . & 0.035 \\
\hline$X$. ricinicola & XR 4 & + & ++ & + & $(+)$ & +++ & ++ & 0.504 \\
\hline$X$, taraxaci & Хт 11 & . & . & + & + & + & + & $0 \cdot 164$ \\
\hline
\end{tabular}

$*(+)$ represents very weak spots; +++ intense spots.

$\dagger$ From their relative positions on the paper, these spots were only tentatively assumed to represent unsaturated trigalacturonic acid.

$\ddagger$ Reaction mixtures were diluted 100 -fold with $0.01 \mathrm{~N}-\mathrm{HCl}$ for extinction measurement. Reaction period, $24 \mathrm{hr}$.

Although various patterns of breakdown products were transiently found in the reaction mixtures when culture supernatant fluids of xanthomonads were used as the enzyme preparations, the major reaction products from polygalacturonic acid acted upon by concentrated crude polygalacturonic acid trans-eliminase from all Xanthomonas cultures were unsaturated di- and tri-galacturonic acids with lesser amounts of saturated mono- and di-galacturonic acids. It can now be concluded that reports in the earlier literature to the effect that the monomer was not formed by some xanthomonads might stem from: $(a)$ the use of samples too small to permit detection of the galacturonic acid, or $(b)$ enzyme activity insufficient to produce monomer in a quantity detectable by the methods used.

The sequential appearance of the several products of pectic digestion by polygalacturonic acid trans-eliminase-forming Xanthomonas species was followed in culture fluids by paper chromatography of samples taken at $24 \mathrm{hr}$ intervals of incubation. In the medium containing pectin, saturated and unsaturated oligogalacturonides first appeared after $24 \mathrm{hr}$ and then monomer was detected after $48 \mathrm{hr}$. Saturated mono-, di-, and tri-galacturonic acids and unsaturated di- and tri-galacturonic acids were found as major end-products after 7 days of incubation. The sequence was the same, 
but this process was shortened, when polygalacturonic acid replaced the pectin in the culture medium; this suggested that pectinesterase activity might be limiting. After incubation for 4 days in the polygalacturonic acid medium, the sole end-product was galacturonic acid which cannot be utilized further by any Xanthomonas culture examined. Therefore, it is plausible that this uronic acid is one of the real end-products of pectin digestion by Xanthomonas species. These results contrast markedly with the non-accumulation of galacturonic acid in the culture fluid of Erwinia carotovora (Kraght \& Starr, 1953); but this organism can rapidly metabolize galacturonic acid through the pathway elucidated by Kilgore \& Starr (1959).

Supported in part by research grant GM-12643 from the National Institute of General Medical Sciences, U.S. Public Health Service.

\section{REFERENCES}

Abo-el-Dahab, M. K. (1964). Production of pectic and cellulolytic enzymes by Xanthomonas malvacearum. Phytopathology 54, 597.

Albersheim, P., Neukom, H. \& Deuel, H. (1960). Über die Bildung von ungesättigten Abbauprodukten durch ein pektinabbauendes Enzym. Helv. Chim. Acta 43, 1422.

Block, R., Durrum, E. L. \& Zweig, G. (1955). A Manual of Paper Chromatography and Paper Electrophoresis, 2nd ed. New York: Academic Press.

Burkholder, W. H. \& StarR, M. P. (1948). The generic and specific characters of phytopathogenic species of Pseudomonas and Xanthomonas. Phytopathology 38, 494.

Ceponis, M. J. \& Friedman, B. A. (1959). Pectolytic enzymes of Pseudomonas marginalis and their effects on lettuce. Phytopathology 49, 141.

DYE, D. W. (1960). Pectolytic activity in Xanthomonas. N.Z. J. Sci. 3, 61.

Edstrom, R. D. \& PhafF, H. J. (1964a). Purification and certain properties of pectin trans-eliminase from Aspergillus fonsecaeus. J. biol. Chem. 239, 2403.

Edstrom, R. D. \& Phaff, H. J. (1964b). Eliminative cleavage of pectin and of oligogalacturonide methyl esters by pectin trans-eliminase. J. biol. Chem. 239, 2409.

Goto, M. \& OKABE, N. (1962a). Studies on the characteristics of pectin-methylesterase excreted by Erwinia carotovora (Jones) Holland, with special reference to the comparisons of the enzymes originated from some plants. Ann. phytopathol. Soc. Japan 27, 10.

Goto, M. \& Oкаве, N. (1962 b). Two kinds of pectin-depolymerase secreted by Erwinia carotovora (Jones) Holland. I. The enzyme production as influenced by cultural conditions and kind of isolates. Ann. phytopathol. Soc. Japan 27, 231.

Kilgore, W. W. \& STARr, M. P. (1959). Catabolism of galacturonic and glucuronic acids by Erwinia carotovora. J. biol. Chem. 234, 2227.

Kraght, A. J. \& Starr, M. P. (1953). Pectic enzymes of Erwinia carotovora. Arch. Biochem. Biophys. 42, 271.

LuH, B. S. \& Phaff, H. J. (1954a). Properties of yeast polygalacturonase. Archs. Biochem. Biophys. 48, 23.

LUH, B. S. \& Phaff, H. J. (1954b). End products and mechanism of hydrolysis of pectin and pectic acid by yeast polygalacturonase (YPG). Archs. Biochem. Biophys. 51, 102.

LuH, B. S., Leonard, S. J. \& PhafF, H. J. (1956). Hydrolysis of pectic materials and oligouronides by tomato polygalacturonase. Fd Res. 21, 448.

MCCOlloch, R. J. \& KeRTeSZ, Z. I. (1949). Recent developments of practical significance in the field of pectic enzymes. Fd Technol. 3, 94.

NAGeL, C. W. \& VAUGHN, R. H. (1961 $a$ ). The characteristics of a polygalacturonase produced by Bacillus polymyxa. Archs. Biochem. Biophys. 93, 344.

Nagel, C. W. \& Vaughn, R. H. $(1961 b)$. The degradation of oligogalacturonides by the polygalacturonase of Bacillus polymyxa. Archs. Biochem. Biophys. 94, 328.

NASUno, S. \& STARR, M. P. (1966a). Polygalacturonase of Erwinia carotovora. J. biol.Chem. 241, 5298.

Nasuno, S. \& Starr, M. P. (1966b). Pectic enzymes of Pseudomonas marginalis. Phytopathology 56, 1414.

NASUNo, S. \& STARR, M. P. (1967). Polygalacturonic acid trans-eliminase of Xanthomonas campestris. Biochem. J. (in the press). 
Ozawa, J. \& OKamoto, K. (1956). Conditions for polygalacturonase production by Erwinia species. Nogaku Kenkyu. 44, 81.

Roelofsen, P. A. (1953). Polygalacturonase activity in yeast, Neurospora and tomato extract. Biochem. Biophys. Acta 10, 410.

SABET, K. A. \& Dowson, W. J. (1951). Action of phytopathogenic bacteria on pectate gel. Nature, Lond. 168, 605.

SMITH, W. K. (1958a). A survey of the production of pectic enzymes by plant pathogenic and other bacteria. J. gen. Microbiol. 18, 33.

SмIтн, W. K. (1958b). Chromatographic examination of the products of digestion of pectic materials by culture solutions of plant pathogenic and other bacteria. J. gen. Microbiol. 18, 42.

StaRr, M. P. (1947). The causal agent of bacterial root and stem disease of guayule. Phytopathology 37, 291.

STARR, M. P. \& Moran, F. (1962). Eliminative split of pectic substances by phytopathogenic soft-rot bacteria. Science 135, 920.

StaRr, M. P. \& Nasuno, S. (1963). Degradation of pectic substances by Xanthomonas campestris. Bact. Proc. p. 116.

Stolp, H., Stark, M. P. \& Baigent, N. L. (1965). Problems in speciation of phytopathogenic pseudomonads and xanthomonads. Ann. Rev. Phytopath. 3, 231.

Winstead, N. N. \& WALker, J. C. (1954). Production of vascular browning by metabolites from several pathogens. Phytopathology 44, 153.

YEMM, E. W. (1935). The respiration of barley plants. I. Methods for the determination of carbohydrates in leaves. Proc. R. Soc. B 117, 483. 